\title{
Trends in socioeconomic inequalities in amenable mortality in urban areas of Spanish cities, 1996-2007
}

Andreu Nolasco ${ }^{1 *}$, José Antonio Quesada ${ }^{1}$, Joaquín Moncho ${ }^{1}$, Inmaculada Melchor ${ }^{1,2}$, Pamela Pereyra-Zamora ${ }^{1}$, Nayara Tamayo-Fonseca ${ }^{1}$, Miguel Angel Martínez-Beneito ${ }^{3,5}$ and Oscar Zurriaga ${ }^{4,5}$

\begin{abstract}
Background: While research continues into indicators such as preventable and amenable mortality in order to evaluate quality, access, and equity in the healthcare, it is also necessary to continue identifying the areas of greatest risk owing to these causes of death in urban areas of large cities, where a large part of the population is concentrated, in order to carry out specific actions and reduce inequalities in mortality. This study describes inequalities in amenable mortality in relation to socioeconomic status in small urban areas, and analyses their evolution over the course of the periods 1996-99, 2000-2003 and 2004-2007 in three major cities in the Spanish Mediterranean coast (Alicante, Castellón, and Valencia).

Methods: All deaths attributed to amenable causes were analysed among non-institutionalised residents in the three cities studied over the course of the study periods. Census tracts for the cities were grouped into 3 socioeconomic status levels, from higher to lower levels of deprivation, using 5 indicators obtained from the 2001 Spanish Population Census. For each city, the relative risks of death were estimated between socioeconomic status levels using Poisson's Regression models, adjusted for age and study period, and distinguishing between genders.

Results: Amenable mortality contributes significantly to general mortality (around 10\%, higher among men), having decreased over time in the three cities studied for men and women. In the three cities studied, with a high degree of consistency, it has been seen that the risks of mortality are greater in areas of higher deprivation, and that these excesses have not significantly modified over time.

Conclusions: Although amenable mortality decreases over the time period studied, the socioeconomic inequalities observed are maintained in the three cities. Areas have been identified that display excesses in amenable mortality, potentially attributable to differences in the healthcare system, associated with areas of greater deprivation. Action must be taken in these areas of greater inequality in order to reduce the health inequalities detected. The causes behind socioeconomic inequalities in amenable mortality must be studied in depth.
\end{abstract}

Keywords: Inequalities in health, Equity in healthcare, Amenable mortality, Small area analysis, Urban areas

\footnotetext{
* Correspondence: nolasco@ua.es

'Unidad de Investigación de Análisis de la Mortalidad y Estadísticas Sanitarias.

Departamento de Enfermería Comunitaria, Medicina Preventiva y Salud Pública e

Historia de la Ciencia, Universidad de Alicante Campus de San Vicente del Raspeig

$\mathrm{s} / \mathrm{n}$, Apartado 99, 03080 Alicante, España

Full list of author information is available at the end of the article
} 


\section{Background}

Avoidable mortality, as an indicator for the quality of healthcare services, was first introduced by Rustein in 1976, who presented the first theoretical study on this issue, where he proposed a list of unnecessary diseases and disabilities or unnecessary untimely deaths, based on the assertion that if health services had acted correctly, they would have been prevented or delayed [1]. Its definition and conceptualisation, as well as the list of causes of death included therein, has evolved over time adapting to medical and technological advances [2-9].

Avoidable mortality is divided into two groups, according to the characteristics of the healthcare intervention 1) Amenable mortality: related with secondary prevention and directly with healthcare intervention, in other words access to healthcare, advice, diagnosis, or treatment: and 2) Preventable mortality: related with primary prevention, lifestyle habits, intervention programmes, etc. [10].

Given that the quality of healthcare and fair access to it must be considered objectives of health policy, amenable mortality can be considered an indicator of potential weaknesses in the healthcare system, in order to study these weaknesses in greater depth and has been used for decades to show the positive impact of healthcare on the health of the population in many industrialised countries $[5,11]$.

Studies conducted in different countries have related certain population socioeconomic indicators with avoidable mortality and, in particular, with amenable, pointing to higher mortality rates among the more underprivileged groups [12-23]. These inequalities are in themselves a risk factor for the health of the population, and they must be studied in order to identify the most vulnerable groups and regions, and be able to carry out specific interventions [24].

In recent decades, improvements in living conditions and growing accessibility to healthcare assistance have led to a reduction in premature mortality and, therefore, avoidable mortality, both amenable and preventable. Various studies evaluating trends in avoidable mortality over time in specific regions or groups have shown this decline $[5,7,25-30]$. Some studies that have linked this temporal evolution with socioeconomic inequalities have suggested that socioeconomic inequalities in avoidable mortality have remained and even increased in recent years $[12,18,20,23,31]$. Other studies that have analysed avoidable mortality in small areas, or which combine this analysis with a study of the association observed with indicators of inequality, have demonstrated an important link between the most depressed areas and those with the highest levels of mortality [14,19,32-34].

Research continues into indicators such as preventable and amenable mortality in order to evaluate quality, access, and equity in the healthcare system [9,35-37]. It is also necessary to continue identifying the areas of greatest risk owing to these causes of death in urban areas of large cities, where a large part of the population is concentrated, in order to carry out specific actions and reduce inequalities in mortality. In Spain, to date, there have been no studies conducted to ascertain the evolution of amenable avoidable mortality and its association with socioeconomic status in small areas of large cities.

The objective of this study is to analyse the temporal evolution of amenable mortality between 1996 and 2007 and its association with socioeconomic status in small areas (census tracts) of the three largest cities, province capitals, of the Comunitat Valenciana (Spain): Alicante, Castellón, and Valencia.

\section{Methods}

This study was performed within the framework of the MEDEA project $[38,39]$. This is a transversal ecological study of amenable mortality in the cities of Alicante, Castellón, and Valencia in the period (P) 1996-2007. These cities are located on the south east coast of Spain (Mediterranean coast), in the region of the Comunitat Valenciana (CV). All the deaths corresponded to noninstitutionalised individuals residing in these three cities during the study period. The deaths were georeferenced by census tract and were obtained from databases used with permission of the CV Death Register Office. The causes of death between 1996 and 1998 were encoded in accordance with the International Classification of Diseases, 9th Version (ICD-9), and the deaths that took place between 1999 and 2007 were classified using the 10th version (ICD-10).

The causes of amenable deaths analysed in the study were those proposed by Nolte and McKee, see Table 1 , and following the criterion defined by these authors, only $50 \%$ of the deaths due to Ischaemic Heart Disease were included $[7,11]$.

The unit of analysis for each city was the Census Tract (CT). CT urban structure of the cities belonging to 2001 was used. According to the population census for the year 2001, the city of Alicante had 284,580 inhabitants, Castellón 147,667, and Valencia 737,219. The number of CTs studied were 215 for Alicante, 95 in Castellón, and 553 in Valencia. The average population size for the CTs studied was 1355 inhabitants.

In each city, the socioeconomic status (SES) of each $\mathrm{CT}$ was established using the following indicators (in percentages):

\section{Unemployed}

Percentage of people aged 16 or over without work (unemployed and those looking for work for the first time), in relation to the total active population. 
Table 1 Frequencies and percentages (by city and sex), classification codes ICD-9 and ICD-10, and age range for the amenable causes studied

\begin{tabular}{|c|c|c|c|c|c|c|c|c|c|c|c|}
\hline & \multirow[t]{2}{*}{ CAUSE } & \multirow[t]{2}{*}{ ICD-9 } & \multirow[t]{2}{*}{ ICD-10 } & \multirow[t]{2}{*}{ AGE } & \multirow[t]{2}{*}{ Sex } & \multicolumn{2}{|c|}{ Alicante } & \multicolumn{2}{|c|}{ Castellón } & \multicolumn{2}{|c|}{ Valencia } \\
\hline & & & & & & $\mathrm{n}$ & $\%$ & $n$ & $\%$ & $\mathrm{n}$ & $\%$ \\
\hline \multirow[t]{2}{*}{1} & Intestinal infections & & & & M & 0 & 0.0 & 1 & 0.1 & 2 & 0.0 \\
\hline & & 002-009 & A00-A09 & $0-14$ & F & 0 & 0.0 & 0 & 0.0 & 0 & 0.0 \\
\hline \multirow[t]{2}{*}{2} & Tuberculosis & 010-018, & A15-A19, & & M & 25 & 1.6 & 11 & 1.4 & 41 & 0.9 \\
\hline & & 137 & B90 & $0-74$ & F & 4 & 0.3 & 4 & 0.6 & 12 & 0.3 \\
\hline \multirow[t]{2}{*}{3} & Other infections (diphtheria, tetanus, poliomyelitis) & 032 & A36, A35, & & M & 0 & 0.0 & 0 & 0.0 & 2 & 0.0 \\
\hline & & 037,045 & A80 & $0-74$ & F & 0 & 0.0 & 0 & 0.0 & 0 & 0.0 \\
\hline \multirow[t]{2}{*}{4} & Whooping cough & & & & M & 0 & 0.0 & 0 & 0.0 & 0 & 0.0 \\
\hline & & 033 & A37 & $0-14$ & F & 0 & 0.0 & 0 & 0.0 & 0 & 0.0 \\
\hline \multirow[t]{2}{*}{5} & Septicaemia & & & & M & 58 & 3.7 & 13 & 1.7 & 115 & 2.5 \\
\hline & & 038 & A40-A41 & $0-74$ & $\mathrm{~F}$ & 22 & 1.8 & 9 & 1.4 & 70 & 2.0 \\
\hline \multirow[t]{2}{*}{6} & Measles & & & & M & 0 & 0.0 & 0 & 0.0 & 0 & 0.0 \\
\hline & & 055 & B05 & $1-14$ & F & 0 & 0.0 & 0 & 0.0 & 0 & 0.0 \\
\hline \multirow[t]{2}{*}{7} & Malignant neoplasm of colon and rectum & & & & M & 269 & 17.3 & 144 & 18.8 & 846 & 18.7 \\
\hline & & $153-154$ & $\mathrm{C} 18-\mathrm{C} 21$ & $0-74$ & F & 201 & 16.2 & 114 & 18.1 & 508 & 14.4 \\
\hline \multirow[t]{2}{*}{8} & Malignant neoplasm of skin & & & & M & 3 & 0.2 & 0 & 0.0 & 14 & 0.3 \\
\hline & & 173 & C44 & $0-74$ & F & 3 & 0.2 & 1 & 0.2 & 4 & 0.1 \\
\hline \multirow[t]{2}{*}{9} & Malignant neoplasm of breast & & & & M & 2 & 0.1 & 0 & 0.0 & 4 & 0.1 \\
\hline & & 174 & $\mathrm{C} 50$ & $0-74$ & $\mathrm{~F}$ & 317 & 25.5 & 140 & 22.2 & 950 & 26.9 \\
\hline \multirow[t]{2}{*}{10} & Malignant neoplasm of cervix uteri & & & & M & 0 & 0.0 & 0 & 0.0 & 0 & 0.0 \\
\hline & & 180 & C53 & $0-74$ & $\mathrm{~F}$ & 38 & 3.1 & 21 & 3.3 & 118 & 3.3 \\
\hline \multirow[t]{2}{*}{11} & Malignant neoplasm of cervix uteri and body uterus & & & & M & 0 & 0.0 & 0 & 0.0 & 0 & 0.0 \\
\hline & & 179,182 & C54-C55 & $0-44$ & $\mathrm{~F}$ & 2 & 0.2 & 0 & 0.0 & 4 & 0.1 \\
\hline \multirow[t]{2}{*}{12} & Malignant neoplasm of testis & & & & M & 3 & 0.2 & 1 & 0.1 & 7 & 0.2 \\
\hline & & 186 & C62 & $0-74$ & $\mathrm{~F}$ & 0 & 0.0 & 0 & 0.0 & 0 & 0.0 \\
\hline \multirow[t]{2}{*}{13} & Hodgkin's disease & & & & M & 6 & 0.4 & 3 & 0.4 & 13 & 0.3 \\
\hline & & 201 & C81 & $0-74$ & F & 2 & 0.2 & 4 & 0.6 & 18 & 0.5 \\
\hline 14 & Leukaemia & & & & M & 12 & 0.8 & 10 & 1.3 & 50 & 1.1 \\
\hline & & $204-208$ & C91-C95 & $0-44$ & $\mathrm{~F}$ & 11 & 0.9 & 5 & 0.8 & 23 & 0.7 \\
\hline 15 & Diseases of the thyroid & & & & M & 3 & 0.2 & 1 & 0.1 & 1 & 0.0 \\
\hline & & $240-246$ & E00-E07 & $0-74$ & $\mathrm{~F}$ & 6 & 0.5 & 1 & 0.2 & 13 & 0.4 \\
\hline 16 & Diabetes & & & & M & 7 & 0.5 & 5 & 0.7 & 19 & 0.4 \\
\hline & & 250 & E10-E14 & $0-49$ & $\mathrm{~F}$ & 2 & 0.2 & 1 & 0.2 & 6 & 0.2 \\
\hline 17 & Epilepsy & & & & M & 8 & 0.5 & 4 & 0.5 & 22 & 0.5 \\
\hline & & 345 & G40-G41 & $0-74$ & F & 4 & 0.3 & 3 & 0.5 & 21 & 0.6 \\
\hline 18 & Chronic rheumatic heart disease & & & & M & 21 & 1.4 & 10 & 1.3 & 70 & 1.5 \\
\hline & & 393-398 & $105-109$ & $0-74$ & $\mathrm{~F}$ & 36 & 2.9 & 34 & 5.4 & 148 & 4.2 \\
\hline 19 & Hypertensive disease & & $110-113$ & & M & 37 & 2.4 & 23 & 3.0 & 99 & 2.2 \\
\hline & & $401-405$ & 115 & $0-74$ & F & 31 & 2.5 & 20 & 3.2 & 89 & 2.5 \\
\hline 20 & Ischaemic heart disease: $50 \%$ of deaths & & & & M & 510 & 32.9 & 234 & 30.6 & 1366 & 30.2 \\
\hline & & $410-414$ & $120-125$ & $0-74$ & $\mathrm{~F}$ & 185 & 14.9 & 79 & 12.5 & 394 & 11.2 \\
\hline 21 & Cerebrovascular diseases & & & & M & 352 & 22.7 & 205 & 26.8 & 1059 & 23.4 \\
\hline & & $430-438$ & $160-169$ & $0-74$ & F & 238 & 19.2 & 116 & 18.4 & 719 & 20.4 \\
\hline
\end{tabular}


Table 1 Frequencies and percentages (by city and sex), classification codes ICD-9 and ICD-10, and age range for the amenable causes studied (Continued)

\begin{tabular}{|c|c|c|c|c|c|c|c|c|c|c|c|}
\hline \multirow[t]{2}{*}{22} & All respiratory diseases & $460-479$ & J00-J09, & & M & 0 & 0.0 & 1 & 0.1 & 3 & 0.1 \\
\hline & & $488-519$ & J20-J99 & $1-14$ & $\mathrm{~F}$ & 0 & 0.0 & 0 & 0.0 & 3 & 0.1 \\
\hline \multirow[t]{2}{*}{23} & Influenza & & & & M & 0 & 0.0 & 0 & 0.0 & 2 & 0.0 \\
\hline & & 487 & J10-J11 & $0-74$ & $\mathrm{~F}$ & 0 & 0.0 & 0 & 0.0 & 7 & 0.2 \\
\hline \multirow[t]{2}{*}{24} & Pneumonia & & & & M & 84 & 5.4 & 35 & 4.6 & 351 & 7.8 \\
\hline & & $480-486$ & J12-J18 & $0-74$ & $\mathrm{~F}$ & 34 & 2.7 & 17 & 2.7 & 157 & 4.4 \\
\hline \multirow[t]{2}{*}{25} & Peptic ulcer & & & & M & 24 & 1.5 & 6 & 0.8 & 48 & 1.1 \\
\hline & & $531-533$ & K25-K27 & $0-74$ & $\mathrm{~F}$ & 7 & 0.6 & 4 & 0.6 & 13 & 0.4 \\
\hline \multirow[t]{2}{*}{26} & Appendicitis & & & & M & 1 & 0.1 & 2 & 0.3 & 8 & 0.2 \\
\hline & & $540-543$ & K35-K38 & $0-74$ & $\mathrm{~F}$ & 1 & 0.1 & 1 & 0.2 & 4 & 0.1 \\
\hline \multirow[t]{2}{*}{27} & Abdominal hernia & & & & M & 1 & 0.1 & 3 & 0.4 & 8 & 0.2 \\
\hline & & $550-553$ & K40-K46 & $0-74$ & $\mathrm{~F}$ & 1 & 0.1 & 3 & 0.5 & 15 & 0.4 \\
\hline \multirow[t]{2}{*}{28} & Cholelithiasis and cholecystitis & & & & M & 8 & 0.5 & 9 & 1.2 & 30 & 0.7 \\
\hline & & $574-575.1$ & K80-K81 & $0-74$ & $\mathrm{~F}$ & 6 & 0.5 & 5 & 0.8 & 22 & 0.6 \\
\hline \multirow[t]{2}{*}{29} & Nephritis and nephrosis & & N00-N07, & & M & 66 & 4.3 & 22 & 2.9 & 188 & 4.2 \\
\hline & & $580-589$ & N17-N19, N25-N27 & $0-74$ & $\mathrm{~F}$ & 46 & 3.7 & 21 & 3.3 & 97 & 2.7 \\
\hline \multirow[t]{2}{*}{30} & Benign prostatic hyperplasia & & & & M & 1 & 0.1 & 0 & 0.0 & 2 & 0.0 \\
\hline & & 600 & $\mathrm{~N} 40$ & $0-74$ & $\mathrm{~F}$ & 0 & 0.0 & 0 & 0.0 & 0 & 0.0 \\
\hline \multirow[t]{2}{*}{31} & Maternal death & & & & M & 0 & 0.0 & 0 & 0.0 & 0 & 0.0 \\
\hline & & $630-676$ & 000-099 & All & $\mathrm{F}$ & 2 & 0.2 & 0 & 0.0 & 3 & 0.1 \\
\hline \multirow[t]{2}{*}{32} & Congenital cardiovascular anomalies & & & & M & 15 & 1.0 & 9 & 1.2 & 52 & 1.1 \\
\hline & & $745-747$ & Q20-Q28 & $0-74$ & $\mathrm{~F}$ & 15 & 1.2 & 9 & 1.4 & 39 & 1.1 \\
\hline \multirow[t]{2}{*}{33} & Perinatal deaths & & P00-P96, & & M & 34 & 2.2 & 12 & 1.6 & 101 & 2.2 \\
\hline & & $760-779$ & A33, A34 & All & $\mathrm{F}$ & 26 & 2.1 & 17 & 2.7 & 72 & 2.0 \\
\hline \multirow[t]{4}{*}{34} & Misadventures to patients & E870-E876, & Y60-Y69, & & M & 1 & 0.1 & 0 & 0.0 & 4 & 0.1 \\
\hline & & E878-E879 & Y83-Y84 & All & $\mathrm{F}$ & 2 & 0.2 & 1 & 0.2 & 2 & 0.1 \\
\hline & TOTAL AMENABLE & & & & M & 1551 & 100.0 & 764 & 100.0 & 4527 & 100.0 \\
\hline & & & & & $\mathrm{F}$ & 1242 & 100.0 & 630 & 100.0 & 3531 & 100.0 \\
\hline
\end{tabular}

\section{Low level of education}

Percentage of people aged 16 or over who, according to the lists from the National Institute of Statistics, cannot read or write, or can read and write but have fewer than 5 years' schooling, or went to school for 5 or more years but did not complete their primary studies, in relation to the total population aged 16 or over.

\section{Low level of education among young people}

Percentage of people aged 16 to 29 with a low level of education in relation to the total population aged 16 to 29 .

\section{Manual workers}

Percentage of people aged 16 or over who have a manual job (employees in the following sectors: services, agriculture, fishing, artisan work, specialist workers in manufacturing industries, construction, mining, installation operators, and non-specialist workers) in relation to the total number of people aged 16 or over in employment.

\section{Temporary workers}

Percentage of people aged 16 or over in temporary employment (part-time self-employed workers, temporary workers), in relation to the total number of people aged 16 or over in employment.

These indicators were used previously in the MEDEA project. Their capacity to classify census tracts by socioeconomic status has been demonstrated in a prior study [34]. On the basis of these indicators, three levels were selected for the SES: SES1 (most privileged socioeconomic status) includes all CTs with values below the 25th percentile in the 5 indicators, SES3 (least privileged socioeconomic status) represents all $\mathrm{CTs}$ with values above the 75th percentile; the remaining CTs were included in SES2 (intermediate socioeconomic 
status). The databases of indicators were freely available and were obtained from the Population and Housing Census - 2001 of the Spanish National Statistics Institute.

Table 2 shows the distribution of CTs and population by SES. Figure 1 shows the geographical distribution of the CTs by SES for the three cities studied.

The populations by CT, age and sex used to calculate mortality indices for the years studied were obtained with permission from the Register Office of the Valencian Institute of Statistics, which is responsible for compiling population statistics in this region.

To study the evolution of the risk of death over time, the data were classified into three time periods: 1996-1999 (P1), 2000-2003 (P2), and 2004-2007 (P3). Deaths were also grouped by age range: $0-49,50-64$, and $65-74$ years of age.

The number and percentage of deaths were calculated for each cause, by sex, period, and city, along with the specific mortality rates (per 100,000 inhabitants). Age Standardised Rates (ASR) have been calculated for each city, sex, period, and SES, using the Spanish population of 2001 as the standard population. Poisson regression models were adjusted using the logarithm of the death rate to estimate the Relative Risks (RR) of death, and their corresponding intervals of confidence at $95 \%$, for each level of the explanatory variables SES, period, and age group [40]. Interaction between SES and period, SES and age group, and age group and period was studied. Possible overdispersion of the models was controlled [41]. The statistical software package $\mathrm{R}$ version 2.12.2 was used for analysis. All the analyses were separated by sex.

\section{Ethical review}

All data used in the analysis have been routinely collected by government statistical agencies, and were anonymized before they were supplied to us. Under these conditions, national regulations do not require ethical review of study proposals.

\section{Results}

Amenable mortality represents approximately $10 \%$ of total mortality, for men and women, and for the three cities studied (Table 2). Among men, there were 1551 deaths in Alicante, 764 in Castellón and 4527 in Valencia. Among women, there were 1242, 630, and 3531 deaths in each city, respectively.

By time periods, for the three cities studied, there is a slight decline in amenable mortality from $12 \%$ in the first period to $10 \%$ in the third period, approximately (Table 2).

The most frequent cause of amenable mortality with regard to the total for amenable causes was ischaemic heart disease (IHD) for men, with $32.9 \%$ in Alicante, $30.7 \%$ in Castellón, and $30.2 \%$ in Valencia (Table 1). Among women, the most frequent cause of death was breast tumour, representing $22.2 \%, 19.7 \%$ and $26.9 \%$ in each city, respectively. The second most frequent amenable cause among men and women was cerebrovascular diseases in the three cities, with percentages between $17 \%$ and $23 \%$ among men, and $16 \%$ and $20 \%$ among women.

Table 3 shows the specific rates of amenable mortality by sex, period, and age. In overall, the specific rates of amenable mortality are higher in the least privileged group in the three periods, but there are some exceptions

Table 2 Number of Census Tracts (CTs) and population of 2001 (Pop) by SES level, and frequencies and percentages of death due to amenable mortality (AM) in comparison to total mortality (TM), by sex, period, and city

\begin{tabular}{|c|c|c|c|c|c|c|c|c|c|c|c|c|c|c|c|c|}
\hline \multirow[t]{2}{*}{ CITY } & \multicolumn{2}{|c|}{ SES1 } & \multicolumn{2}{|c|}{ SES2 } & \multicolumn{2}{|c|}{ SES3 } & \multirow[t]{2}{*}{ TYPE MORTAL } & \multirow[t]{2}{*}{ SEX } & \multicolumn{2}{|c|}{$1996-99$} & \multicolumn{2}{|c|}{$2000-03$} & \multicolumn{2}{|c|}{ 2004-07 } & \multicolumn{2}{|c|}{ 1996-2007 } \\
\hline & CTs & Pop & CTs & Pop & CTs & Pop & & & $\mathrm{n}$ & $\%$ & $\mathrm{n}$ & $\%$ & $\mathrm{n}$ & $\%$ & $\mathrm{n}$ & $\%$ \\
\hline \multirow[t]{4}{*}{ Alicante } & 15 & 21404 & 180 & 218224 & 20 & 22856 & AM & $M$ & 551 & 11.8 & 525 & 10.7 & 475 & 9.8 & 1551 & 10.7 \\
\hline & & & & & & & & $\mathrm{F}$ & 471 & 11.6 & 393 & 9.5 & 378 & 8.7 & 1242 & 9.9 \\
\hline & & & & & & & $\mathrm{TM}$ & $M$ & 4682 & 100.0 & 4893 & 100.0 & 4854 & 100.0 & 14429 & 100.0 \\
\hline & & & & & & & & $\mathrm{F}$ & 4046 & 100.0 & 4158 & 100.0 & 4366 & 100.0 & 12570 & 100.0 \\
\hline \multirow[t]{4}{*}{ Castellón } & 6 & 10266 & 84 & 118144 & 5 & 8418 & AM & $M$ & 304 & 12.0 & 220 & 8.5 & 240 & 9.3 & 764 & 9.9 \\
\hline & & & & & & & & $\mathrm{F}$ & 230 & 10.9 & 191 & 8.6 & 209 & 9.3 & 630 & 9.6 \\
\hline & & & & & & & $\mathrm{TM}$ & $M$ & 2542 & 100.0 & 2598 & 100.0 & 2583 & 100.0 & 7723 & 100.0 \\
\hline & & & & & & & & $\mathrm{F}$ & 2107 & 100.0 & 2232 & 100.0 & 2253 & 100.0 & 6592 & 100.0 \\
\hline \multirow[t]{4}{*}{ Valencia } & 53 & 62859 & 456 & 576146 & 44 & 49370 & AM & $M$ & 1693 & 11.6 & 1502 & 10.6 & 1332 & 9.6 & 4527 & 10.6 \\
\hline & & & & & & & & $\mathrm{F}$ & 1351 & 10.3 & 1155 & 8.7 & 1025 & 7.4 & 3531 & 8.8 \\
\hline & & & & & & & $\mathrm{TM}$ & $M$ & 14578 & 100.0 & 14109 & 100.0 & 13931 & 100.0 & 42618 & 100.0 \\
\hline & & & & & & & & $\mathrm{F}$ & 13177 & 100.0 & 13293 & 100.0 & 13870 & 100.0 & 40340 & 100.0 \\
\hline
\end{tabular}




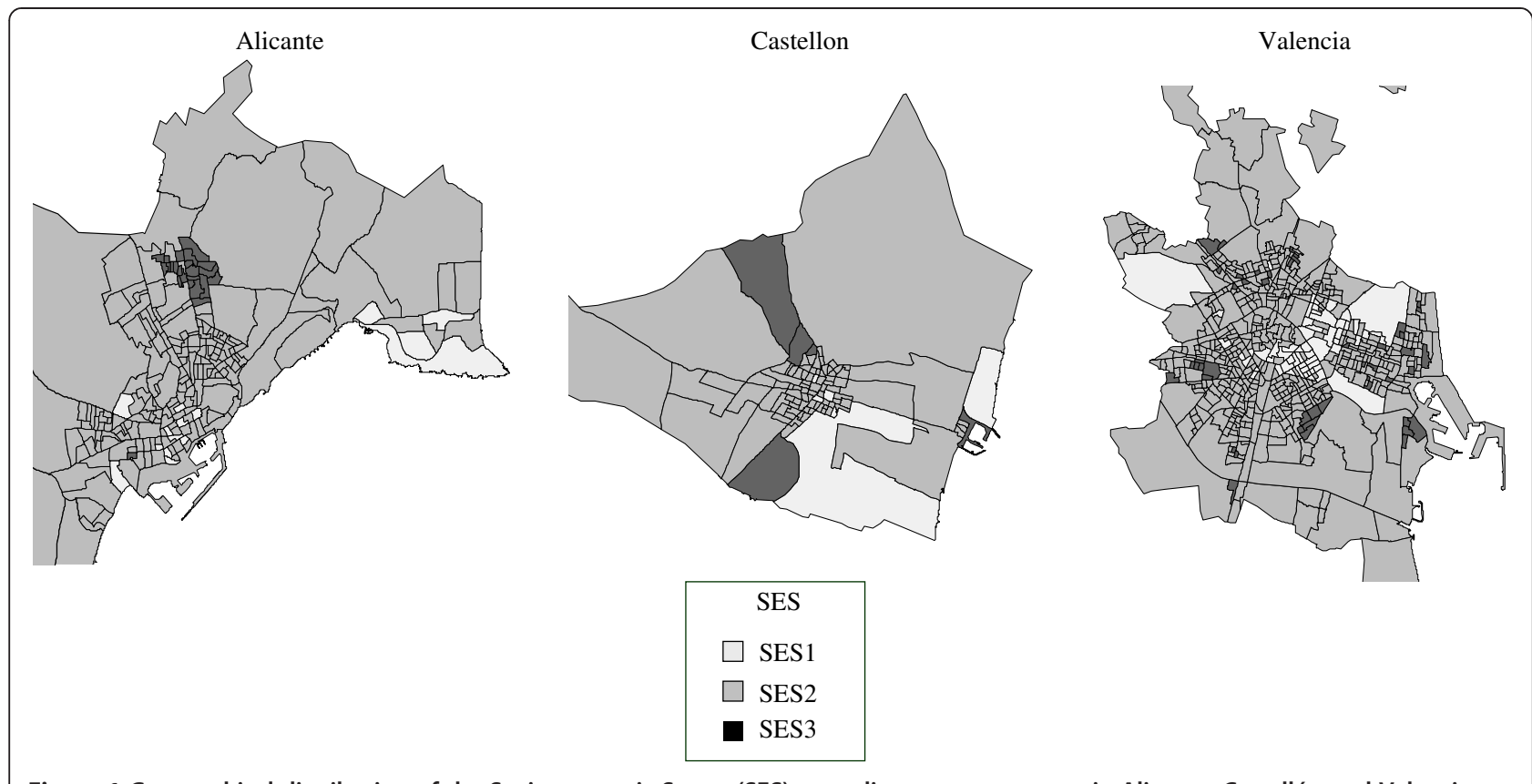

Figure 1 Geographical distribution of the Socioeconomic Status (SES) according to census tracts in Alicante, Castellón and Valencia.

that suggest that the relative risk between the SES levels be evaluated globally. Figure 2 shows the evolution of the ASR (logASR) by SES level for each city, and sex. As can be observed, there is a decrease of the ASR from the first period to the last one, with differences depending on city and sex, in all cases, except for SES1 in Castellón for women. For men, the decrease of the ASR was slightly higher in SES1 in Alicante and higher in SES3 in Castellón and Valencia. The distance between SES1 and SES3 increased from the first period to the last one only in Alicante, and decreased the most in Castellón. For women, the decrease in the ASR was similar in SES1 and SES3 in Alicante and Valencia, whereas they decreased in SES3 and slightly increased in SES1 in Castellón. The distances between SES1 and SES3 were very similar in the first and last period, slightly lower in the last period in Castellón.

Table 4 shows the Relative Risks (RR) of death and their confidence intervals at $95 \%$ obtained using Poisson regression models with explanatory variables SES, age, and period. It cannot be stated that inequalities in the risks of death according to SES have changed significantly over the time periods studied, since there is no significant interaction between SES and period in any of the cases studied. For men, in Alicante, the risk of death is $1.5(1.1-1.9)$ times higher when they are in the most underprivileged group SES3 in comparison with SES1, and the risk of death decreases in the third period in comparison with the first, $R R=0.8(0.7-0.9)$. In Castellón, the risk of death decreases in P2 and P3 in comparison with P1. In this city, differences due to SES are not significant among men, although the values for relative risk among SES levels are similar to those obtained in the other two cities. In Valencia, the relative risk of death is 0.8 (0.7-0.8) in P3 and 0.9 (0.8-0.9) in P2 in comparison with $\mathrm{P} 1$, and the risk of death is $1.4(1.2-1.6)$ times higher in SES3 than in SES1.

Among women, in the three cities, the risk of death decreases in P2 and P3 in comparison to P1. By SES, the risk of death in SES3 is 1.8 (1.3-2.4) times higher than for SES1 in Alicante, and 1.7 (1.1-2.6) times higher in Castellón. In Valencia, this risk is 1.8 (1.3-2.4) times higher in the 50-64 age group and 1.5 (1.2-1.8) times higher in the 65-74 age range, since there is a significant interaction between SES and age group.

\section{Discussion}

Using data from three major Spanish cities, basic socioeconomic indicators of the educational and working environment have been used in this study to examine socioeconomic inequalities in amenable mortality and thus evaluate equity in the effectiveness of the health service. The existence of inequalities in amenable mortality should highlight the differences in the result of healthcare provision between groups from different socioeconomic status. Consideration of a cause of death as amenable was based on the existence of effective interventions to prevent it. The results of this study show that amenable mortality makes a significant contribution to general mortality (around 10\%, higher among men), having decreased over time in the three cities studied for men and women. Results are consistent, since in the three cities studied the risks of death are higher in areas 
Table 3 Specific rates $(x 100.000)$ of amenable mortality by sex, period, age, socioeconomic status level (SES), and city

\begin{tabular}{|c|c|c|c|c|c|c|c|c|c|c|}
\hline \multicolumn{11}{|l|}{ MALE } \\
\hline \multicolumn{2}{|c|}{ Period (years) } & \multicolumn{3}{|c|}{ ALICANTE } & \multicolumn{3}{|c|}{ CASTELLÓN } & \multicolumn{3}{|c|}{ VALENCIA } \\
\hline & & $0-49$ & $50-64$ & $65-74$ & $0-49$ & $50-64$ & $65-74$ & $0-49$ & $50-64$ & $65-74$ \\
\hline \multirow[t]{3}{*}{ 1996-99 } & SES1 & 13,1 & 131,4 & 717,7 & 24,4 & 112,1 & 420,2 & 19,1 & 162,2 & 568,6 \\
\hline & SES2 & 24,8 & 171,4 & 730,5 & 22,5 & 209,5 & 832,4 & 23,3 & 223,9 & 781,9 \\
\hline & SES3 & 13,4 & 214,4 & 877,8 & 8,0 & 272,6 & 881,5 & 33,2 & 259,9 & 819,7 \\
\hline \multirow[t]{3}{*}{ 2000-03 } & SES1 & 12,7 & 108,2 & 624,3 & 6,2 & 175,5 & 493,9 & 20,6 & 136,1 & 614,3 \\
\hline & SES2 & 17,5 & 162,0 & 680,2 & 15,6 & 115,6 & 575,7 & 21,7 & 177,7 & 673,8 \\
\hline & SES3 & 28,2 & 185,9 & 667,7 & 23,5 & 167,7 & 687,8 & 36,6 & 189,6 & 754,3 \\
\hline \multirow[t]{3}{*}{ 2004-07 } & SES1 & 9,9 & 80,4 & 437,4 & 17,1 & 64,5 & 482,2 & 23,1 & 121,2 & 550,8 \\
\hline & SES2 & 16,7 & 140,4 & 564,8 & 18,0 & 145,3 & 560,1 & 19,9 & 155,9 & 570,1 \\
\hline & SES3 & 23,7 & 223,7 & 583,4 & 18,0 & 247,0 & 257,1 & 26,6 & 267,8 & 565,7 \\
\hline \multicolumn{11}{|l|}{ FEMALE } \\
\hline \multicolumn{2}{|c|}{ Period (years) } & \multicolumn{3}{|c|}{ ALICANTE } & \multicolumn{3}{|c|}{ CASTELLÓN } & \multicolumn{3}{|c|}{ VALENCIA } \\
\hline & & $0-49$ & $50-64$ & $65-74$ & $0-49$ & $50-64$ & $65-74$ & $0-49$ & $50-64$ & $65-74$ \\
\hline \multirow[t]{3}{*}{ 1996-99 } & SES1 & 22,2 & 121,3 & 205,6 & 6,6 & 109,6 & 411,2 & 22,1 & 85,1 & 304,9 \\
\hline & SES2 & 20,9 & 145,1 & 466,1 & 19,5 & 133,6 & 496,0 & 25,0 & 141,1 & 448,5 \\
\hline & SES3 & 17,1 & 179,7 & 518,2 & 32,3 & 235,1 & 738,5 & 16,1 & 192,4 & 494,1 \\
\hline \multirow[t]{3}{*}{$2000-03$} & SES1 & 9,1 & 50,0 & 361,0 & 18,0 & 89,2 & 252,3 & 27,4 & 105,0 & 342,1 \\
\hline & SES2 & 15,7 & 118,3 & 346,1 & 18,0 & 125,7 & 336,5 & 22,6 & 110,4 & 355,2 \\
\hline & SES3 & 27,9 & 121,9 & 613,6 & 16,2 & 182,0 & 462,2 & 18,0 & 175,5 & 468,3 \\
\hline \multirow[t]{3}{*}{ 2004-07 } & SES1 & 22,0 & 71,6 & 182,3 & 19,3 & 53,4 & 485,7 & 10,8 & 82,9 & 283,0 \\
\hline & SES2 & 15,3 & 117,4 & 316,9 & 19,0 & 100,3 & 388,2 & 20,5 & 110,5 & 306,5 \\
\hline & SES3 & 22,6 & 158,2 & 332,8 & 30,8 & 84,6 & 643,2 & 17,6 & 113,1 & 403,9 \\
\hline
\end{tabular}

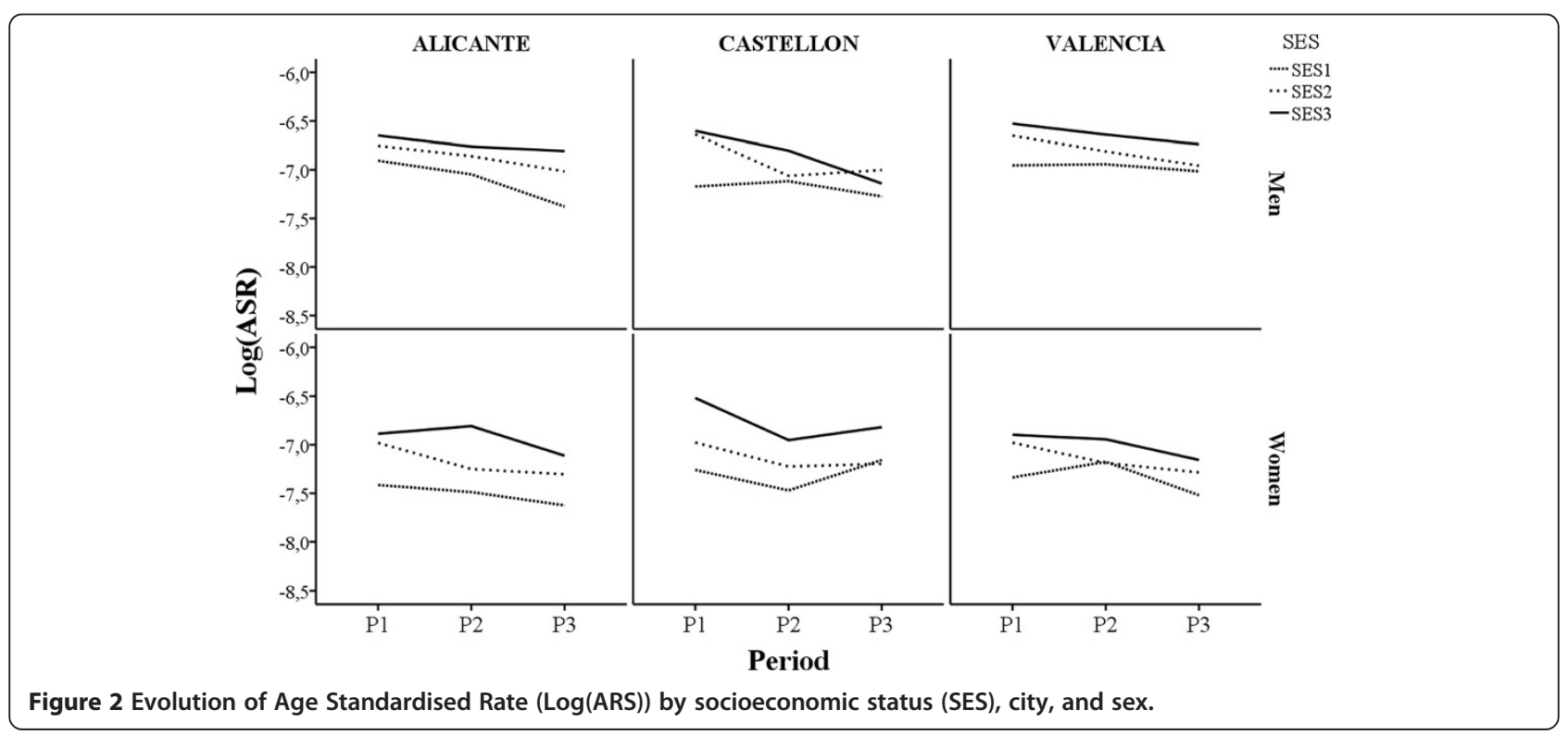


Table 4 Adjusted Relative Risks (RR) of death and confidence intervals at $95 \%$ for age, period, and socioeconomic status, according to city and sex

\begin{tabular}{|c|c|c|c|}
\hline & & \multicolumn{2}{|c|}{ RR of death $-\mathrm{Cl}$ at $95 \%\left({ }^{*}\right)$} \\
\hline & & MEN & WOMEN \\
\hline \multicolumn{4}{|c|}{ ALICANTE } \\
\hline \multirow[t]{3}{*}{ Age } & $00-49$ & 1 & 1 \\
\hline & $50-64$ & $8.2(7.0-9.7)$ & $7.1(6.0-8.4)$ \\
\hline & $65-74$ & $\mathbf{3 4 . 2}(29.6-39.5)$ & $21.1(18.1-24.7)$ \\
\hline \multirow[t]{3}{*}{ Period } & $96-99$ & 1 & 1 \\
\hline & $00-03$ & $0.9(0.8-1.0)$ & $\mathbf{0 . 8}(0.7-0.9)$ \\
\hline & $04-07$ & $\mathbf{0 . 8}(0.7-0.9)$ & $\mathbf{0 . 7}(0.6-0.8)$ \\
\hline \multirow[t]{3}{*}{ SES } & SES1 & 1 & 1 \\
\hline & SES2 & $1.3(1.0-1.6)$ & $1.4(1.1-1.8)$ \\
\hline & SES3 & $1.5(1.1-1.9)$ & $1.8(1.3-2.4)$ \\
\hline \multicolumn{4}{|c|}{ CASTELLÓN } \\
\hline \multirow[t]{3}{*}{ Age } & 00-49 & 1 & 1 \\
\hline & $50-64$ & $8.4(6.7-10.5)$ & $6.3(5.0-7.9)$ \\
\hline & $65-74$ & $34.2(27.9-41.9)$ & $21.9(17.8-27.0)$ \\
\hline \multirow[t]{3}{*}{ Period } & $96-99$ & 1 & 1 \\
\hline & $00-03$ & $\mathbf{0 . 7}(0.6-0.8)$ & $0.8(0.6-0.9)$ \\
\hline & $04-07$ & $0.7(0.6-0.8)$ & $\mathbf{0 . 8}(0.7-0.9)$ \\
\hline \multirow[t]{3}{*}{ SES } & SES1 & 1 & 1 \\
\hline & SES2 & $1.3(0.9-1.7)$ & $1.1(0.8-1.6)$ \\
\hline & SES3 & $1.4(0.9-2.1)$ & $1.7(1.1-2.6)$ \\
\hline
\end{tabular}

VALENCIA

\begin{tabular}{llll} 
Age & $00-49$ & 1 & \\
& $50-64$ & $\mathbf{8 . 3}(7.6-9.1)$ & $(* *)$ \\
Period & $65-74$ & $\mathbf{2 9 . 8}(27.4-32.4)$ & \\
& $96-99$ & 1 & 1 \\
& $00-03$ & $\mathbf{0 . 9}(0.8-0.9)$ & $\mathbf{0 . 8}(0.8-0.9)$ \\
SES & $04-07$ & $\mathbf{0 . 8}(0.7-0.8)$ & $\mathbf{0 . 7}(0.7-0.8)$ \\
& SES1 & 1 & \\
& SES2 & $\mathbf{1 . 2}(1.1-1.3)$ & $(* *)$ \\
$\left(*^{* *}\right) 00-49$ & SES3 & $\mathbf{1 . 4}(1.2-1.6)$ & \\
& SES1 & & 1 \\
& SES2 & & $1.1(0.9-1.5)$ \\
& SES3 & & $0.9(0.6-1.3)$ \\
$(* *) 50-64$ & SES1 & & 1 \\
& SES2 & & $\mathbf{1 . 3}(1.0-1.6)$ \\
& SES3 & & $\mathbf{1 . 8}(1.3-2.4)$ \\
$(* *) 65-74$ & SES1 & & 1 \\
& SES2 & & $1.2(1.0-1.4)$ \\
& SES3 & & $\mathbf{1 . 5}(1.2-1.8)$ \\
\hline
\end{tabular}

$\left(*^{*}\right)$ In bold, RR are statistically significant at $95 \%$.

$(* *)$ Owing to the existence of significant interaction between age and SES for women, the RRs for the SES are shown in each of the age groups. of greater deprivation, and these excesses have not modified over time.

The percentage of amenable deaths with regard to general mortality has been decreasing over the three study periods, for men and women, in the three cities studied. The decrease observed for amenable mortality over time agrees with the results obtained in other studies suggesting that improvements in health services have contributed significantly to the improvement of the population's health in recent years $[11,18,19,23,26,28,42]$. The decreasing trend in amenable mortality found in this study is similar to that found for preventable mortality in Spain in other studies $[43,44]$.

The socioeconomic inequalities found are along the same lines as those observed in other studies. For example, Tobias and Yeh found that amenable causes make an important contribution to the mortality differentials between socio-economic groups in New Zealand, with data from 1981-84 and 2001-04 [8]. Furthermore, Nagy, et al., examining data from 2004 to 2008, found a relationship between the risks of death due to amenable causes and deprivation in geographical areas of Hungary [22]. Schoenbaum, et al. provided evidence of excessive amenable mortality in areas with higher populations of poor and black people in the US in 2005 [21]. In the city of New York, Althoff, et al. found that disparities in the mortality due to several amenable causes of poor and wealthy have not narrowed between 1989-91 and 19992001 [45]. Using data from 14 European countries (including Spain for the city of Barcelona and the regions of Madrid and the Basque Country), Plug, et al. observed the presence of inequalities in amenable mortality regarding level of education [44].

In relation to the evolution of socioeconomic inequalities over time, this study does not find evidence of modification between the periods studied with regard to inequalities between socioeconomic status levels in any of the three cities, since the effects of interaction between SES and the study period were not significant, possibly indicating that inequalities have remained constant in both periods. This result coincides with the findings of some studies but counters the results of others. Korda, et al., looking at small areas of Australia, observed that amenable mortality decreased significantly but more so among the highest levels of SES between 1986 and 2002 [18]. James, et al. observed a reduction in socioeconomic differences in amenable mortality in Canada between 1971 and 1996, maintaining significant inequalities [26]. In Finland, Lumme, et al. observed, using data from 1992 to 2008 , that in spite of the decrease in amenable mortality rates, socioeconomic differences have increased, coinciding with the findings of McCallum, et al. for that same country $[23,30]$. In Canada, James, et al. found a significant decrease in socioeconomic inequalities in amenable 
mortality in urban areas, between 1971 and 1996, although this was not the same for preventable mortality owing to public health policies [19].

The findings of this study can be compared with those obtained by the authors in a previous study conducted on the same cities, with the same socioeconomic indicators, census tracts, and a similar methodology to estimate socioeconomic inequalities in preventable avoidable mortality with data from 1996 to 2003 [34]. In that research, higher risks of death were found owing to causes of preventable mortality in the most underprivileged areas, but they were greater than those obtained here for amenable mortality among men (relative risks above 2 in the three cities), and lower among women (only the city of Valencia presented a value significantly higher than 1 ). However, the results obtained from this study point to excesses in the risk of death in areas with a lower socioeconomic status that are similar among men and women, and in all three cities, suggesting that the effect of socioeconomic inequalities on amenable mortality is more homogenous than on preventable mortality. The interaction detected between the effect of SES and the effect of age among women in the city of Valencia nuances the interpretation of excess mortality among more under privileged SES levels, establishing a significant excess risk only among older women ( $>50$ years of age).

In relation to the classification by SES used in this work, it is worth mentioning that the relative risks estimated between the most and least privileged categories represent the relative risk between the worst and bestoff population group in all the indicators used. Hence, the interpretation of these relative risks differs from that obtained using other classifications based on percentiles or on the continuous value of a compound socioeconomic indicator based on the originals, and indicates the level of extreme inequalities, between categories that can be identified as being of maximum and minimum deprivation. This classification identifies areas of maximum deprivation, susceptible to greater vigilance and attention.

The most common cause of amenable mortality in this study for men was ischaemic heart disease, although only $50 \%$ of deaths were included, which was also the third most frequent cause of death for women. In a recent study conducted in small areas of nine major cities in Spain, a decrease in mortality owing to this cause was found over time in small areas of Spanish cities between 1996 and 2007, coinciding with the decrease in amenable mortality found here [46]. The socioeconomic inequalities found in this study for this cause were greater among women than among men, which cannot be firmly asserted for amenable mortality studied as a whole in this article since, although the relative risks of death estimated between levels of SES are slightly higher among women, they do not present significant differences with men, which suggests the socioeconomic inequalities in amenable mortality are similar in the two sexes.

Amenable mortality has been used for decades to assess health care delivery. Recent studies have confirmed that such indicator is useful to establish the impact of health care innovation on population's health. However, they suggest that amenable mortality should be interpreted with caution when being used as an indicator of health care performance, especially when comparing different countries, for this indicator may reflect the influence of health care and other factors $[36,47,48]$. Our study confirms, on the one hand, the idea that amenable mortality is related not only to health care delivery but also to other factors. Socioeconomic inequalities found show not only an unequal health care delivery but also many other unequal socioeconomic factors that influence mortality. On the other hand, this study has been performed in urban areas, where the overall population has health insurance and medical coverage. Furthermore, the three cities have a common health care policy framework, and hence, the innovations and improvements were introduced at the same time for the whole population. These conditions suggest that health care delivery may have an independent effect on amenable mortality, which may not confound the effect of other factors that belong to socioeconomic status because of the conditions described above (overall medical coverage and health insurance, urban areas, similar policy framework...), which make it difficult to think about an association between socioeconomic factors and health care delivery. These conditions are different to the ones in the study of Shoenbaum et al., carried out on United States population with different health insurance and medical coverage. This study described the association between amenable mortality and indicators related to both health care and socioeconomic factors, and concluded that it is important to adjust the effect of one on the other [21].

The causes of inequality observed between socioeconomic status levels can be complex.

On the one hand, the differences found might pertain to different access to and quality of healthcare according to SES, as suggested in various studies, so that higher income population segments are more likely to see a specialist $[49,50]$. However, other studies have not found any links between inequalities in the use of healthcare and amenable mortality [44]. On the other, the prevalence, incidence, and natural course of some diseases might have an effect on amenable mortality and differ between socioeconomic groups, since the exposure to its risk factors might also differ. Survival following treatment might also be affected by different resources according to socioeconomic status (social support, resources at home, medical insurance, etc.). These possible differences have not been taken into account in this study. Regardless of accessibility and 
the quality of services, people's socioeconomic status will be related with their level of culture, and can influence aspects such as self-care, and access to information about the health-disease process, factors that influence the way in which healthcare services are accessed and used. Hence, for many amenable causes, there is access to healthcare services but they are not used in the early stages of the diseases; people reach the healthcare system when their condition has worsened, and there might be a direct influence between the patient's trajectory of selfcare and mortality.

This study was conducted during a period in which the Spanish Healthcare System offers universal and free access to all citizens, differentiating it from other countries where this is not the case. This starting point is favourable to reducing mortality and to achieve equity but does not guarantee it, as shown by the results of this and other studies $[37,51,52]$.

This study presents certain limitations. Firstly, it is an ecological study, with all the limitations this kind of study brings. Thus, it does not allow the proof of a causal association. The association found between SES and mortality using CTs may not be applicable at an individual level (i.e. ecological fallacy). With reference to the causes analysed, the list used could have differed. The choice of these causes responded to a criterion of comparability with many other studies. The consistency of the results obtained indicates that they would not have been substantially different from those obtained using a different list with minor variations. Hence, the inclusion of $50 \%$ of deaths due to ischaemic heart disease was revised, recalculating the relative risks between levels of SES with $100 \%$ of deaths, but no substantial variations were found in the estimations. Another limitation could pertain to the use of different classifications of mortality over the period of study, which were felt to be minimal, given the experience of the encoding team from the Death Register Office, which was the same throughout the period of study. The classification of census tracts by SES was carried out using accumulated data from the 2001 census and was the same for the entire period of study. The year 2001 is right in the middle of the study period and it was thought that there would not be substantial variations over the course of this period. Another aspect to consider is that avoidable mortality only takes account of deaths and no other health results, offering an incomplete vision of the benefits of healthcare. Furthermore, as mentioned previously, the causes of socioeconomic differences in amenable mortality can come from a complex model in which differences in the prevalence or incidence of diseases are involved, along with differences in pre and post treatment resources, and even biases in access to and quality of healthcare.
Inequalities in health, and specifically the differences reflected in amenable mortality, which emerge between the least and the more privileged groups in the population, is undoubtedly one of the greatest challenges faced by healthcare policies and modern healthcare systems. The differences in avoidable mortality, preventable or amenable, are usually the reflection of an unequal system, and their analysis is essential in order to understand in detail the weaknesses of the system, and to take effective actions.

The period studied in this article concludes in 2007, coinciding with the start of the current global economic crisis that is having such a major effect on Spain. As such, this work could provide a point of reference for future studies that assess the evolution of inequalities in subsequent periods.

\section{Conclusions}

This study consistently highlights that, although amenable mortality decreases over time, its socioeconomic inequalities are maintained in the three cities. Areas have been identified that show excesses in amenable mortality, potentially attributable to deficiencies in the healthcare system, and associated with low socioeconomic level. These are the higher risk areas where action must be taken to reduce inequalities in health detected. It is necessary, therefore, to study in depth the causes of socioeconomic inequalities in amenable mortality.

\section{Abbreviations \\ CV: Comunitat Valenciana; ICD-9: International classification of diseases, 9th version; ICD-10: International classification of diseases, 10th version; CT: Census tract; SES: Socioeconomic status; SES1: Most privileged socioeconomic status; SES2: Intermediate socioeconomic status; SES1: Least privileged socioeconomic status; P1: Time period 1996-1999; P2: Time period 2000-2003; P3: Time period 2004-2007; RR: Relative risk; IHD: Ischaemic heart disease.}

\section{Competing interests}

The authors declare that they have no competing interests.

\section{Authors' contributions}

The study was conceived and designed collectively by all the authors. AN and JAQ coordinated and conducted the analysis and wrote the first version of the manuscript. All the authors contributed equally to the analysis of the data, interpretation, and discussion of results. All the authors have read and approved the final version.

\section{Acknowledgements}

This work was partly supported by the FIS-FEDER projects PI040170 and PI080330.

We would like to thank Marc Nolasco Miñana for his help and assistance with the final translation of the text.

\section{Author details}

${ }^{1}$ Unidad de Investigación de Análisis de la Mortalidad y Estadísticas Sanitarias. Departamento de Enfermería Comunitaria, Medicina Preventiva y Salud Pública e Historia de la Ciencia, Universidad de Alicante Campus de San Vicente del Raspeig s/n, Apartado 99, 03080 Alicante, España. ${ }^{2}$ Registro de Mortalidad de la Comunidad Valenciana. Servicio de Estudios Epidemiológicos y Estadísticas Sanitarias, Subdirección General de Epidemiología y Vigilancia de la Salud. Conselleria de Sanitat, Plaza de España 6, 03010 Alicante, España. ${ }^{3}$ Área de 
Desigualdades en Salud. FISABIO-CSISP. Conselleria de Sanitat, Avenida de Cataluña, 21, 46020 Valencia, España. ${ }^{4}$ Servicio de Estudios Epidemiológicos y Estadísticas Sanitarias, Subdirección General de Epidemiología y Vigilancia de la Salud. Conselleria de Sanitat, Avenida de Cataluña, 21, 46020 Valencia, España. ${ }^{5}$ Consorcio de Investigación Biomédica en Red de Epidemiología y Salud Pública (CIBERESP), Instituto de Salud Carlos III Melchor Fernández Almagro, 3-5 28029 Madrid, España.

Received: 9 January 2014 Accepted: 28 March 2014 Published: 1 April 2014

\section{References}

1. Rustein D, Berenberg W, Charmers TC, Child C, Fishnet A, Perrin E: Measuring the quality of medical care. N Engl J Med 1976, 294:582-588.

2. Charlton JR, Hartley RM, Silver R, Holland WW: Geographical variation in mortality from conditions amenable to medical intervention in England and Wales. Lancet 1983, 1(8326 Pt 1):691-6.

3. Holland WW: European Community Atlas of Avoidable Death. Commission of the European Communities Health Services Research Series No. 3. Brussels: Oxford University Press; 1988.

4. Mackenbach JP, Kunst AE, Looman CWN, Habbema JDF, Van Der Maas PJ: Regional differences in mortality from conditions amenable to medical interventions in The Netherlands: a comparison of four time periods. J Epidemiol Community HealtH 1988, 42:325-332.

5. Nolte E, Mckee M: Does Health Care save lives? Avoidable mortality revisited. London: Nuffield Trust; 2004.

6. Gispert R, Barés MA, Puigdefabregas A: La mortalidad evitable: lista de consenso para la actualización del indicador en España. Gac Sanit 2006, 20:184-193.

7. Nolte $E_{1}$ McKee M: Measuring the health of nations: updating an earlier analysis. Health Aff 2008, 27:58-71.

8. Tobias M, Yeh L: How much does health care contribute to health gain and to health inequality? Trends in amenable mortality in New Zealand 1981-2004. Aust N Z J Public Health 2009, 33:70-78.

9. AMIEHS working group, Hoffmann R, Plug I, Khoshaba B, McKee M, Mackenback JP: Amenable mortality revisited: The AMIEHS study. Gac Sanit 2013, 27:199-206.

10. Holland WW: European Community Atlas of Avoidable Death. Commission of the European Communities Health Services Research Series No. 6. Brussels: Oxford University Press; 1991

11. Nolte E, Mckee M: Variations in amenable mortality-Trends in 16 high-income nations. Health Policy 2011, 103:47-52.

12. Piers L, Carson N, Brown K, Ansari Z: Avoidable mortality in Victoria between 1976 and 2001. Aust N Z J Public Health 2007, 31:5-12.

13. Mackenbach JP, Stirbu I, Roskam AJ, Schaap MM, Menvielle G, Leinsalu M, Kunst AE: Socioeconomic Inequalities in Health in 22 European Countries. N Engl J Med 2008, 2008(358):2468-2481.

14. Cano-Serral G, Azlor E, Rodriguez-Sanz M, Pasarín MI, Martinez JM, Pugpinós R Muntaner C, Borrell C: Socioeconomic inequalities in mortality in Barcelona: A study based on census tracts (MEDEA project). Health Place 2009, 15:186-192.

15. Butler DC, Petterson S, Bazemore A, Douglas KA: Use of measures of socioeconomic deprivation in planning primary health care workforce and defining health care need in Australia. Aust J Rural Health 2010, 18:199-204.

16. Kunitz SJ, McKee M, Nolte E: State political cultures and the mortality of African Americans and American Indians. Health Place 2010, 16:558-566.

17. Stirbu I, Kunst A, Bopp M, Leinsalu M, Regidor E, Esnaola S, Costa G, Martikainen P, Borrell C, Deboosere P, Kalediene P, Rychtarikova J, Artnik B, MacKenbach J: Educational inequalities in avoidable mortality in Europe. J Epidemiol Community Health 2010, 64:913-920.

18. Korda RJ, Butler JR, Clements M, Kunitz S: Differential impacts of health care in Australia: trend analysis of socioeconomic inequalities in avoidable mortality. Int J Epidemiol 2007, 36:157-165.

19. James P, Wilkins R, Detsky A, Tugwell P, Douglas G: Avoidable mortality by neighbourhood income in Canada: 25 years after the establishment of universal health insurance. J Epidemiol Community Health 2007, 61:287-296.

20. Weisz D, Gusmano M, Rodwin V, Neuberg L: Population health and the health system: a comparative analysis of avoidable mortality in three nations and their world cities. Eur J Public Health 2007, 18:166-172.
21. Schoenbaum S, Schoen C, Nicholson J, Cantor J: Mortality amenable to Health Care in the United States: The role of Demographics and Health Systems Performance. J Public Health Policy 2011, 32:407-429.

22. Nagy C, Juhasz A, Beale L, Páldy A: Mortality amenable to health care and its relation to socio-economic status in Hungary, 2004-08. Eur J Public Health 2011, 22:620-624.

23. Lumme $S$, Sund R, Leyland A, Keskimaki I: Socioeconomic equity in amenable mortality in Finland 1992-2008. Soc Sci Med 2012, 75:905-913.

24. Rodríguez-Sanz M, Carrillo P, Borrell C: Desigualdades sociales en la salud, los estilos de vida y la utilización de servicios sanitarios en las CC.AA., 1993-2003. Observatorio de la Mujer, Secretaria General de Sanidad, Ministerio de Sanidad y Consumo; 2006. Available at: http:/wwww.msssi.gob.es/organizacion/ sns/planCalidadSNS/pdf/equidad/Desigualdades_sociales_salud_y_SS.pdf (acessed on October 8, 2013).

25. Cayuela A, Rodriguez-Dominguez S, Otero R: Evolución de la mortalidad por cáncer de pulmón en las provincias de Andalucía (1975-2002). Arch Bronconeumol 2006, 42:633-7.

26. James P, Manuel D, Mao Y: Avoidable mortality across Canada from 1975 to 1999. BMC Public Health 2006, 23:137.

27. Gispert R, Serra I, Bares MA, Puig X, Puigdefábregas A, Freitas A: The impact of avoidable mortality on life expectancy at birth in Spain: changes between three periods, from 1987 to 2001. J Epidemiol Community Health 2008, 62:783-789.

28. Chung Jl, Song YM, Choi JS, Kim BM: Trends in Avoidable Death over 20 years in Korea. J Korean Med Sci 2008, 23:975-81.

29. Autier P, Boniol M, LaVecchia C, Vatten L, Gavin A, Héry C, Heanue M: Disparities in breast cáncer mortality trends between 30 European countries: retrospective trend analysis of WHO mortality database. BMJ 2010, 341:c3620.

30. McCallum A, Manderbacka C, Arffman M, Leyland A, Keskimäki I: Socioeconomic differences in mortality amenable to health care among Finish adults 1992-2003: 12 year follow up using individual level linked population register data. BMC Health Serv Res 2013, 13:3.

31. Borrell C, Rodríguez-Sanz M, Pasarín I, Brugal M, Garcia-de-Olalla P, Marí-Del-Olmo M Caylà J: AIDS mortality before and after the introducction of highly active antiretroviral therapy: does it vary with socioeconomic group in a country with a National Health System? Eur J Public Health 2006, 16:601-608

32. Vergara M, Benach J, Martinez JM, Buxó M, Yasui Y: La mortalidad evitable y no evitable: distribución geográfica en áreas pequeñas de España (1990-2001). Gac Sanit 2009, 23:16-22.

33. Sundmacher L, Kimmerle J, Latzitis N, Busse R: Amenable mortality in Germany: spatial distribution and regional concentrations. Gesundheitswesen 2011, 73:229-237.

34. Nolasco A, Melchor I, Pina JA, Pereyra-Zamora P, Moncho J, Tamayo N, García-Senchermes C, Zurriaga O, Martinez-Beneito MA: Preventable avoidable mortality: Evolution of socioeconomic inequalities in urban areas in Spain, 1996-2003. Health Place 2009, 15:732-741.

35. Tang KK, Petrie D, Rao P: Measuring health inequelities between genders and age groups with realizacion of potencial life years (RePLY). Bull World Health Organ 2007, 85:681-7.

36. Mackenbach JP, Hoffmann R, Khoshaba B, Plug I, Rey G, Westerling R, Parna $\mathrm{K}$, Jougla E, Alfonso J, Looman C, McKee M: Using 'amenable mortality' as indicador of healthcare effectiveness in international comparisions: results of a validation study. J Epidemiol Community Health 2012. doi:10.1136/jech-2012-201471.

37. Quercioli C, Messina G, Basu S, McKee M, Nante N, Stucler D: The effect of healthcare delivery privatisation on avoidable mortality: longitudinal cross-regional results from Italy, 1993-2003. J Epidemiol Community Health 2012, 67:132-138.

38. Dominguez-Berjon MF, Borrell C, Cano-Serral G, Esnaola S, Nolasco A, Pasarin MI, Ramis R, Saurina C, Escolar-Pujolar A: Constructing a deprivation index based on census data in large Spanish cities (the MEDEA project). Gac Sanit 2008, 22:179-187.

39. Borrell C, Mari-Dell'olmo M, Serral G, Gotsens M, and other MEDEA members: Inequalities in mortality in small areas of eleven Spanish cities (the multicenter MEDEA project). Health Place 2010, 16:703-711.

40. Pérez-Hoyos S: Introducción a la regresión de Poisson. Escola Valenciana d'Estudis per a la Salut; 2001.

41. Martínez MA, Morales J: Modelos Lineales Generalizados. Elche(Alicante): Ed. Universidad Miguel Hernandez; 2001. 
42. Chen B, Yang C-Y: Temporal trend analysis of avoidable mortality in Taiwan, 1971-2008: Overall progress, with areas for further medical or public health investment. BMC Public Health 2013, 13:551.

43. Barés MA, Gispert R, Puig X, Pugidefàbregas A, Tresserras R: Distribucion geográfica y evolución temporal de la mortalidad evitable en Cataluña (1986-2001). Gac Sanit 2005, 19:307-15.

44. Plug I, Hoffmann R, Artnik B, Bopp M, Borrell C, Costa G, Deboosere P, Esnaola S, Kalediene R, Leinsalu M, Lundberg O, Martikainen P, Regidor E, Rychtarykova J, Strand B, Wojtyniak B, Mackenbach PJ: Socioeconomic inequalities in mortality from conditions amenable to medical interventions: do they reflect inequalities in access or quality of health care? BMC Public Health 2012, 12:346.

45. Althoff KN, Karpati A, Hero J, Matte T: Secular changes in mortality disparities in New York City: A reexamination. J Urban Health 2009, 86:729-744.

46. Marí Dell'Olmo M, Gotsens M, Borrell C, Martínez-Beneito MA, Palencia L, Pérez G, Cirera L, Daponte A, Domínguez-Berjón F, Esnaola S, Gandarillas A, Lorenzo P, Martos C, Nolasco A, Rodríguez-Sanz M: Trends in socioeconomic inequalities in ischemic heart disease mortality in small areas of 9 Spanish cities from 1996 to 2007: by means of Smoothed ANOVA. J Urban Health 2013. doi:10.1007/s11524-013-9799-6.

47. Hoffmann R, Plug I, McKee M, Khoshaba B, Westerling R, Looman C, Rey G, Jougla E, Alfonso JL, Lang K, Pärna K, Mackenbach JP: Innovations in medical care and mortality trends from four circulatory diseases between 1970 and 2005. Eur J Public Health 2013, 23:852-57.

48. Hoffmann R, Plug I, McKee M, Khoshaba B, Westerling R, Looman C, Rey G, Jougla E, Lang K, Pärna K, Mackenbach JP: Innovations in health care and mortality trends from five cancers in seven European countries between 1970 and 2005. Int J Public Health 2013. doi:10.1007/s00038-013-0507-9.

49. Van Doorslaer E, Wagstaff A, Van der Burg H, Christiansen T, De Graeve D, Duchesne I, Gerdtham U, Gerfin M, Geurts J, Gross L, Häkkinen U, John J, Klavus J, Leu R, Nolan B, O'Donnell O, Propper C, Puffer F, Schellhorn M, Sundberg G, Winkelhake O: Equity in the delivery of health care in Europe and the US. J Health Econ 2000, 19:553-583.

50. Van Doorslaer E, Masseria C, OECD Health Equity Research Group: Inequalities in access to medical care by income in developed countries. CMAJ 2006, 2006(174):177-183.

51. Lee Y-C, Huang Y-T, Tsai Y-W, Huang S-M, Kuo KN, McKee M, Nolte E: The impact of universal National Health Insurance on population health: the experience of Taiwan. BMC Health Serv Res 2010, 10:225.

52. Hernández I, Santaolaya M, Campos P: Las desigualdades sociales en salud y la atención primaria. Informe SESPAS 2012. Gac Sanit 2012, 26:6-13.

\section{Submit your next manuscript to BioMed Central and take full advantage of:}

- Convenient online submission

- Thorough peer review

- No space constraints or color figure charges

- Immediate publication on acceptance

- Inclusion in PubMed, CAS, Scopus and Google Scholar

- Research which is freely available for redistribution

Submit your manuscript at www.biomedcentral.com/submit 